\title{
Development of plasma electrolytic oxidation for improved Ti6Al4V biomaterial surface properties
}

\author{
Krzysztof Rokosz $^{1}$ - Tadeusz Hryniewicz ${ }^{1} \cdot$ Steinar Raaen $^{2}$
}

Received: 4 August 2015 / Accepted: 9 November 2015 /Published online: 18 November 2015

(C) The Author(s) 2015. This article is published with open access at Springerlink.com

\begin{abstract}
In the paper, the scanning electron microscopy (SEM), energy-dispersive X-ray spectroscopy (EDS), and Xray photoelectron spectroscopy (XPS) results of the Ti6Al4V alloy treated by a novel plasma electrolytic oxidation (PEO) (micro arc oxidation) in the electrolyte containing concentrated phosphoric acid and copper nitrate are presented. The PEO treatment was performed at the voltage of $450 \pm 10 \mathrm{~V}$. The main problem to solve under the experiments was to obtain a porous surface layer composed mainly of titanium phosphates within the copper ions. The performed study has shown that the amount of copper nitrate in $85 \%$ concentrated phosphoric acid should be not less than $1.60 \mathrm{~mol} / \mathrm{L}$. The best result in the case of copper $(4.3 \pm 0.6 \mathrm{wt} \%)$ and phosphorus $(19.9 \pm 0.5 \mathrm{wt} \%)$ contents in the surface layer was obtained after the PEO treatment in electrolyte with the highest amount of copper nitrate used, i.e., in $3.20 \mathrm{~mol} / \mathrm{L}$ of $\mathrm{Cu}\left(\mathrm{NO}_{3}\right)_{2}$ in $\mathrm{H}_{3} \mathrm{PO}_{4}$. Concerning the Ti6Al4V alloy for the use as biomaterial, an interesting characteristic and a great advantage obtained from the proposed PEO treatment is eliminating vanadium and a considerable diminishing of aluminum from the surface coating. Two elements forming Ti6Al4V alloy, vanadium, and aluminum are detrimental for
\end{abstract}

Tadeusz Hryniewicz

Tadeusz.Hryniewicz@tu.koszalin.pl

Krzysztof Rokosz

rokosz@tu.koszalin.pl

Steinar Raaen

luki6665@gmail.com; steinar.raaen@ntnu.no

1 Division of Surface Electrochemistry \& Technology, Faculty of Mechanical Engineering, Koszalin University of Technology, Racławicka 15-17, PL 75-620 Koszalin, Poland

2 Department of Physics, Norwegian University of Science and Technology (NTNU), Realfagbygget E3-124 Høgskoleringen 5, NO 7491 Trondheim, Norway human body. After implantation, vanadium leaking from this biomaterial reveals the carcinogenic effects whereas aluminum has an impact on acceleration and stimulation of Alzheimer's disease. Separation and isolation of the human tissue from the matrix is a crucial task of researchers. The proposed new PEO process fulfills this requirement and may result in great improvement of the biomedical surface characteristics.

Keywords Ti6Al4Valloy $\cdot$ Plasma electrolytic oxidation (PEO) treatment · Micro arc oxidation (MAO) · Surface layer . SEM $\cdot$ EDS $\cdot$ XPS

\section{Introduction}

Plasma electrolytic oxidation (PEO) known also as the micro arc oxidation (MAO) [1-4] as well as electrochemical polishing (EP) [5], magnetoelectropolishing (MEP) [5-9], and/or high-current density electropolishing (HDEP) $[10,11]$ operations performed on metals or alloys results in the formation of the surface layer with different specific mechanical [12, $13]$ and corrosion properties [9, 14]. These layers are generally characterized by different chemical compositions [15-18] than that of the matrix itself. The difference in those treatments lies also in the range of processing control, i.e., the electrochemical polishing is controlled by the current density, while in the case of the PEO operations, the voltage is the main control parameter.

The passive/oxide layer after the electropolishing treatment operations is formed with the thickness of 5-10 nm, whereas the thickness of the PEO layer is about 1000 higher, being of the order of about $10 \mu \mathrm{m}$ and has a porous structure. The layers obtained after electropolishing operations are mostly corrosion resistant and enriched in chromium compounds in 
Fig. 1 SEM picture of surface layer formed on Ti6Al4V alloy after $\mathrm{PEO}$ at voltage of $450 \mathrm{~V}$ in $0.05 \mathrm{~mol} / \mathrm{L}$ of $\mathrm{Cu}\left(\mathrm{NO}_{3}\right)_{2}$ in $\mathrm{H}_{3} \mathrm{PO}_{4}$ electrolyte

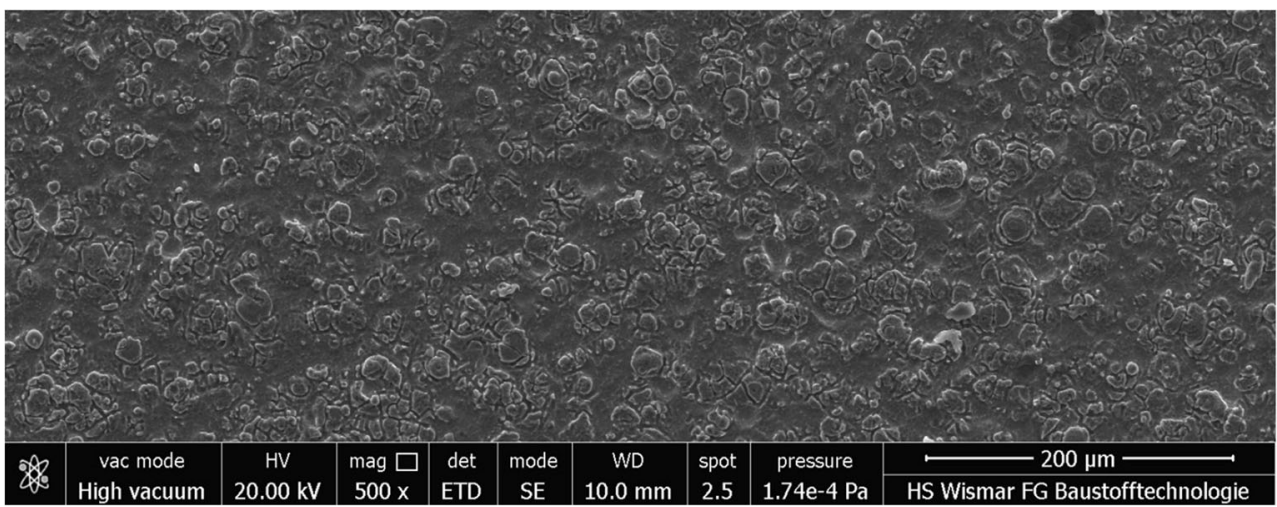

the case of stainless steels or in titanium compounds in the case of titanium alloys treated. Due to these specific features, these oxides are named as "passive." It should be added that after the PEO/MAO operations, the surface layer/coating is generally non-passive. The "non-passive layer" term here refers to the phosphate porous coating under which there is a passive, compact thin film containing mainly titanium oxides. Due to the large number of pores created during the PEO treatment, it is not possible to conclude that the outer porous surface is passive. Because of the biocompatibility needed in the obtained PEO coatings, the most important is to obtain the outer layer with a large number of pores which - if a biomaterial implant is inserted - will be partly absorbed by the human body.

Numerous published papers presenting scanning electron microscopy/energy-dispersive X-ray spectroscopy (SEM/ EDS), X-ray diffraction analysis (XRD), X-ray photoelectron spectroscopy (XPS), and secondary ion mass spectroscopy (SIMS) results indicate that the surface layers formed after each of the EP, MEP, HDEP, and PEO treatments have different chemical compositions and structure (various crystalline and/or amorphous forms) than those of the native matrices [1-18]. Some of them obtained by EP, MEP, and HDEP are passive, and others obtained in PEO/MAO operations are open thick porous layers, generally non-passive [1-4]. The abovementioned nano- and micro-surface layers obtained by the EP, MEP, HDEP, and PEO (MAO) treatments are often formed on biomaterials for their improved biocompatibility [19]. In addition, in some of the operations of PEO/MAO, a special effort is taken for the surface layers to be enriched in the chemical elements like silver and/or copper, which are bactericidal [20-24].

Ti6Al4V is the most widely used titanium alloy of special characteristics, good machinability, and excellent mechanical properties. Its characteristic features cover the high strength, low weight-to-volume ratio, and outstanding corrosion resistance. A wide and diversified range of applications of this titanium alloy includes aerospace and automotive industries, marine applications, chemical industry and oil and gas extraction industry, power generation, sports (e.g., race-car gearbox), and other major industries. In numerous engineering applications, this titanium alloy has replaced heavier, less serviceable and/or less cost-effective materials. All these properties, with the demand for high level of reliable performance, resulted in biomechanical applications, such as implants and prosthesis [2-4, 25-27].

Biocompatibility of Ti6Al4V has been assumed to be excellent, especially when a direct contact with tissue or bone is required. After years of biomedical applications, however, it has been noticed that some of the elements forming this alloy can elude/leak out into the human tissue, resulting in a progressive threat to the human being. Specifically, aluminum and vanadium are the elements that should be avoided due to the detrimental action in the human body [27-29].
Fig. 2 SEM picture of surface layer formed on Ti6Al4V alloy after PEO at voltage of $450 \mathrm{~V}$ in $0.05 \mathrm{~mol} / \mathrm{L}$ of $\mathrm{Cu}\left(\mathrm{NO}_{3}\right)_{2}$ in $\mathrm{H}_{3} \mathrm{PO}_{4}$ electrolyte (higher magnification)

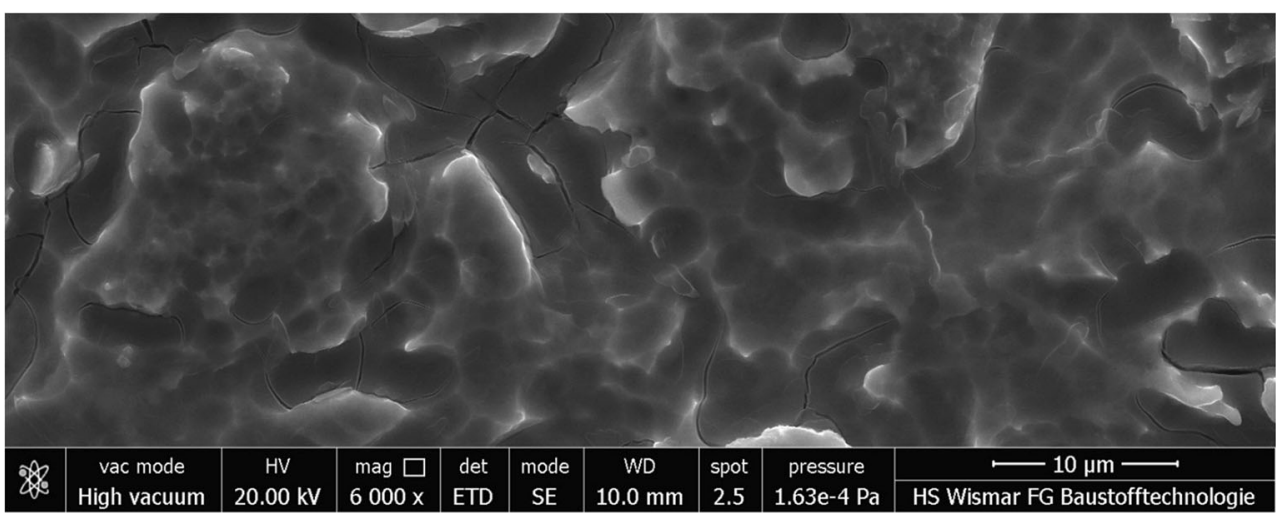


Table 1 Descriptive statistics of the amount of phosphorus, aluminum, titanium, and copper in the surface layer formed on Ti6Al4V alloy after PEO at voltage of $450 \mathrm{~V}$ in electrolyte containing from 0.05 up to $3.20 \mathrm{~mol} / \mathrm{L}$ of $\mathrm{Cu}\left(\mathrm{NO}_{3}\right)_{2}$ in $\mathrm{H}_{3} \mathrm{PO}_{4}$

\begin{tabular}{|c|c|c|c|c|c|c|c|c|c|c|c|c|c|c|c|}
\hline \multirow[t]{2}{*}{$\mathrm{wt} \%$} & \multicolumn{5}{|c|}{$0.05 \mathrm{~mol} / \mathrm{L}$ of $\mathrm{Cu}\left(\mathrm{NO}_{3}\right)_{2}$} & \multicolumn{5}{|c|}{$1.60 \mathrm{~mol} / \mathrm{L}$ of $\mathrm{Cu}\left(\mathrm{NO}_{3}\right)_{2}$ in $\mathrm{H}_{3} \mathrm{PO}_{4}$} & \multicolumn{5}{|c|}{$3.20 \mathrm{~mol} / \mathrm{L}$ of $\mathrm{Cu}\left(\mathrm{NO}_{3}\right)_{2}$ in $\mathrm{H}_{3} \mathrm{PO}_{4}$} \\
\hline & $\mathrm{O}$ & $\mathrm{Al}$ & $\mathrm{P}$ & $\mathrm{Cu}$ & $\mathrm{Ti}$ & $\mathrm{O}$ & $\mathrm{Al}$ & $\mathrm{P}$ & $\mathrm{Cu}$ & $\mathrm{Ti}$ & $\mathrm{O}$ & $\mathrm{Al}$ & $\mathrm{P}$ & $\mathrm{Cu}$ & $\mathrm{Ti}$ \\
\hline Mean & 43.5 & 2.5 & 3.2 & 0 & 50.7 & 53.2 & 1.4 & 19.9 & 2.5 & 30.9 & 51.8 & 1.1 & 19.9 & 4.3 & 22.9 \\
\hline Variance & 0.15 & 0.05 & 0.21 & 0 & 0.42 & 73.35 & 0.08 & 3.8 & 0.11 & 25.75 & 0.45 & 0.01 & 0.26 & 0.33 & 0.38 \\
\hline Standard deviation & 0.4 & 0.2 & 0.5 & 0 & 0.6 & 8.6 & 0.3 & 14.43 & 0.3 & 5.1 & 0.7 & 0.1 & 0.5 & 0.6 & 0.6 \\
\hline Median & 43.5 & 2.5 & 3.3 & 0 & 50.6 & 49.6 & 1.3 & 18.2 & 2.4 & 28.9 & 52 & 1.1 & 19.8 & 4 & 23 \\
\hline Maximum & 44.1 & 2.8 & 3.5 & 0 & 51.7 & 68.5 & 1.9 & 26.6 & 3 & 39.9 & 52.4 & 1.2 & 20.5 & 5.2 & 23.5 \\
\hline Minimum & 43.1 & 2.2 & 2.4 & 0 & 50.1 & 48.9 & 1.2 & 17.4 & 2.2 & 27.7 & 50.8 & 0.9 & 19.4 & 3.9 & 21.9 \\
\hline
\end{tabular}

Nowadays, the Ti6Al4V alloy is still used as a biomaterial [28-31]. It has to be pointed out that vanadium, an alloying element in Ti6A14V alloy, has relatively strong cytotoxicity. Under conditions corresponding to human body (tissue environment), the implant containing metallic vanadium is thermodynamically unstable, located in the area of corrosion, in contrast to pure titanium. Further analysis of the literature concerning biocompatibility of titanium alloys clearly indicates the carcinogenic effects of vanadium [29-33]. The toxic effects of aluminum were also proved concerning the neurotoxicity associated with Alzheimer's disease [27-30, 33-37].

Based on the review of literature and the up-to-date studies, the following hypotheses may be formulated:

1. Most likely, it is possible to obtain a coating based on a phosphate-enriched copper ions by plasma electrolytic oxidation in phosphoric acid within copper nitrate, and

2. It is expected that the amount of copper in the coating depends on the concentration of dissolved copper nitrate in phosphoric acid.

The aim of the work was to create a porous coating on titanium alloy, containing copper ions by the plasma electrolytic oxidation (PEO). The study by all using spectroscopic methods combined with statistical data processing has to prove that goal has been achieved. Additionally, the authors studied the three electrolytes with different amounts of copper nitrate and found out the best one regarding surface porosity and the content of copper within coating.

In this paper, the surface modification by $\mathrm{Cu}$ incorporation in the Ti6Al4V biomaterial alloy has been studied. The authors present the possibility of incorporation of the copper ions into the surface layer by the PEO treatment at the voltage of $450 \mathrm{~V}$ in the electrolyte consisting of concentrated phosphoric acid with copper nitrate.

\section{Method}

\subsection{Material}

The Ti6Al4V (6 \% Al, $4 \%$ V, $90 \%$ Ti) samples cut off from the cold-rolled plate were served for the study. The samples were prepared in the form of rectangular specimens of dimensions $5 \times 30 \times 1.3 \mathrm{~mm}$ and cleaned with acetone before the PEO treatment.

\subsection{PEO setup and parameters}

The plasma electrolytic oxidation (PEO) was performed at the voltage of $450 \pm 10 \mathrm{~V}$. The main elements of the setup were the following: a processing cell, a dc power supply, the

Fig. 3 SEM picture of surface layer formed on Ti6Al4V alloy after PEO at voltage of $450 \mathrm{~V}$ in $1.60 \mathrm{~mol} / \mathrm{L}$ of $\mathrm{Cu}\left(\mathrm{NO}_{3}\right)_{2}$ in $\mathrm{H}_{3} \mathrm{PO}_{4}$ electrolyte

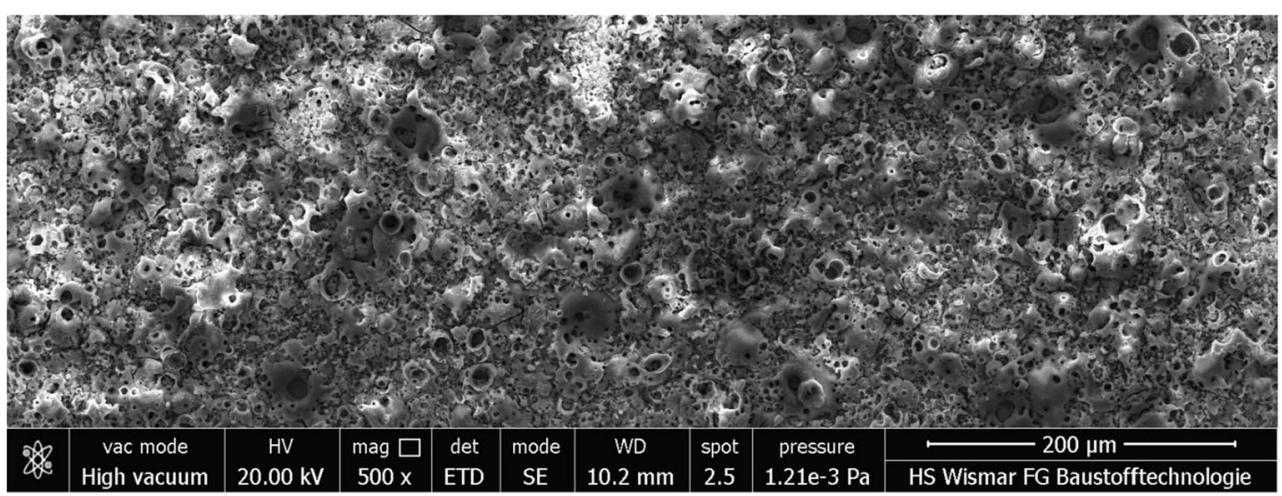


Fig. 4 SEM picture of surface layer formed on Ti6Al4V alloy after PEO at voltage of $450 \mathrm{~V}$ in $1.60 \mathrm{~mol} / \mathrm{L}$ of $\mathrm{Cu}\left(\mathrm{NO}_{3}\right)_{2}$ in $\mathrm{H}_{3} \mathrm{PO}_{4}$ electrolyte (higher magnification)

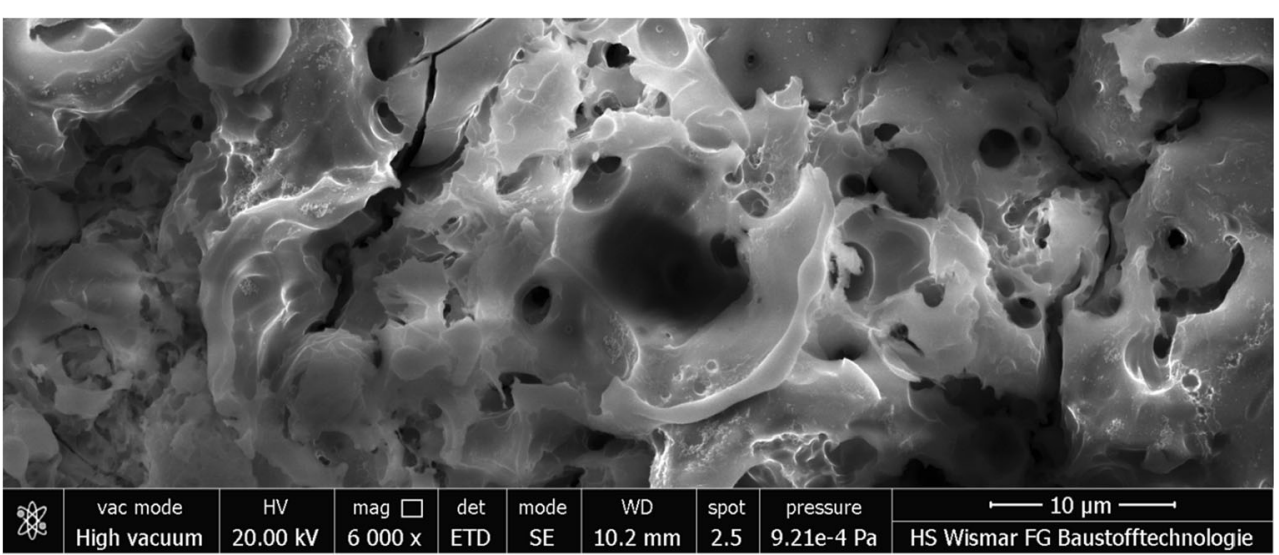

electrodes, and connecting wiring. The studies were carried out in the electrolyte of initial temperature of $20 \pm 2{ }^{\circ} \mathrm{C}$. For the studies, the electrolyte composed of orthophosphoric acid with an addition of copper II nitrate was used. For each run, the electrolytic cell made of glass was used, containing up to $500 \mathrm{~mL}$ of the electrolyte.

\subsection{Setup of SEM/EDS}

The scanning electron microscope Quanta 250 FEI with low vacuum and ESEM mode and a field emission cathode as well as the energy-dispersive EDX system in a Noran System Six with nitrogen-free silicon drift detector were used. The magnifications of 500 and 6000 times for SEM photos were used. The EDS analyses were performed from the whole frame for magnification of $\times 6000$.

\subsection{Setup of XPS}

The XPS measurements on the PEO-treated Ti6A14V samples were performed using SCIENCE SES 2002 instrument using a monochromatic (Gammadata Scienta) Al K(alpha) $(h \nu=$ $1486.6 \mathrm{eV}) \mathrm{X}$-ray source $(18.7 \mathrm{~mA}, 13.02 \mathrm{kV})$. The scan analyses were carried out with the analysis area of $1 \times 3 \mathrm{~mm}$ and a pass energy of $500 \mathrm{eV}$ with the energy step of $0.2 \mathrm{eV}$ and the step time of $200 \mathrm{~ms}$. The binding energy of the spectrometer has been calibrated by the position of the Fermi level on a clean metallic sample. The power supplies were stable and of high accuracy. The experiments were carried out in an ultra-high vacuum system with a base pressure of about $6 \times 10^{-10} \mathrm{~Pa}$. The XPS spectra were recorded in normal emission [10-12, 38-40]. For the XPS analyses, the CasaXPS 2.3.14 software (Shirley background type) was used. The all binding energy values presented in that paper were charge corrected to $\mathrm{C} 1 \mathrm{~s}$ at $284.8 \mathrm{eV}$. The spectra of titanium (Ti $2 p$ ) and phosphorus (P 2p) with nine sweeps, nickel (Ni 2p) and copper $(\mathrm{Cu} 2 \mathrm{p})$ with 16 sweeps, and the oxygen $(\mathrm{O} 1 \mathrm{~s})$ and carbon $(\mathrm{C} 1 \mathrm{~s})$ with four sweeps were studied. Under an additional Ti6Al4V surface layer analysis, it was found that $\mathrm{Al}$ $2 p$ spectrum overlapped with $\mathrm{Cu} 3 p$ spectrum. Because of that overlapping, there was found the real area of $\mathrm{Al} 2 \mathrm{p}$ peak using the two equations:

$$
\begin{array}{r}
\operatorname{Area}(\mathrm{Cu} 3 p)=\operatorname{Area}(\mathrm{Cu} 2 p) \times \frac{\text { R.S.F. }(\mathrm{Cu} 3 p)}{\text { R.S.F. }(\mathrm{Cu} 2 \mathrm{p})}=\operatorname{Area}(\mathrm{Cu} 2 \mathrm{p}) \\
\times 0.0976 \text { Real Area }(\mathrm{Al} \mathrm{2p})=\operatorname{Area}(\mathrm{Al} \mathrm{2p})-\operatorname{Area}(\mathrm{Cu} 3 p)
\end{array}
$$

\section{Results and discussion}

The SEM photos of the surface layer formed on Ti6Al4V alloy after PEO in the electrolyte consisting of $\mathrm{Cu}\left(\mathrm{NO}_{3}\right)_{2}$ and
Fig. 5 SEM picture of surface layer formed on Ti6A14V alloy after PEO at voltage of $450 \mathrm{~V}$ in $3.20 \mathrm{~mol} / \mathrm{L}$ of $\mathrm{Cu}\left(\mathrm{NO}_{3}\right)_{2}$ in $\mathrm{H}_{3} \mathrm{PO}_{4}$ electrolyte

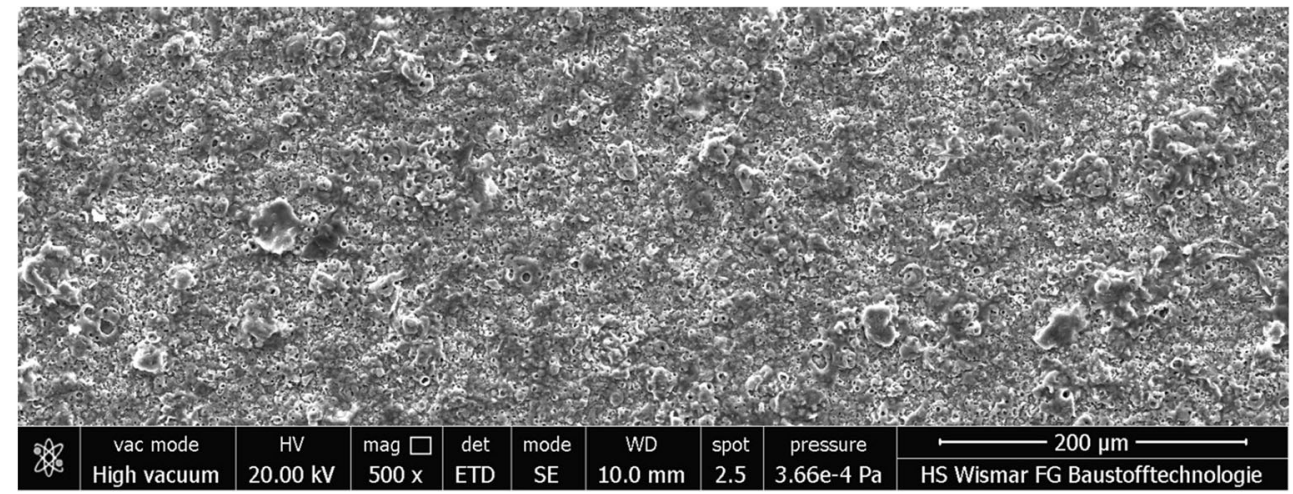


Fig. 6 SEM picture of surface layer formed on Ti6Al4V alloy after $\mathrm{PEO}$ at voltage of $450 \mathrm{~V}$ in $3.20 \mathrm{~mol} / \mathrm{L}$ of $\mathrm{Cu}\left(\mathrm{NO}_{3}\right)_{2}$ in $\mathrm{H}_{3} \mathrm{PO}_{4}$ electrolyte (higher magnification)

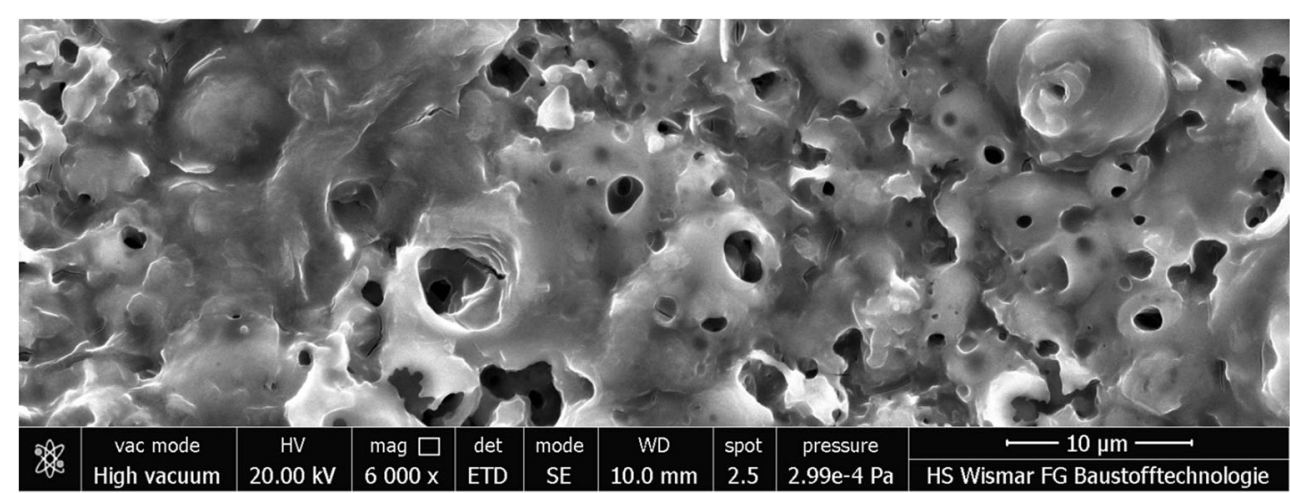

$\mathrm{H}_{3} \mathrm{PO}_{4}$ of $0.05 \mathrm{~mol} / \mathrm{L}$ are shown in Figs. 1 and 2 . The characteristic feature is the surface layer obtained after the PEO treatment in that electrolyte, which is not porous. Looking from above, some forms of the PEO coating in the surface layer may be distinguished. However, after $3 \mathrm{~min}$ of the PEO oxidation, no characteristic porous layer is visible. In
Fig. 7 EDS spectra of the surface layer formed on Ti6Al4V alloy after PEO at the voltage of $450 \mathrm{~V}$ in the electrolyte containing a 0.05 , b 1.60 , and c $3.20 \mathrm{~mol} / \mathrm{L}$ of $\mathrm{Cu}\left(\mathrm{NO}_{3}\right)_{2}$ in $\mathrm{H}_{3} \mathrm{PO}_{4}$ electrolyte (a)

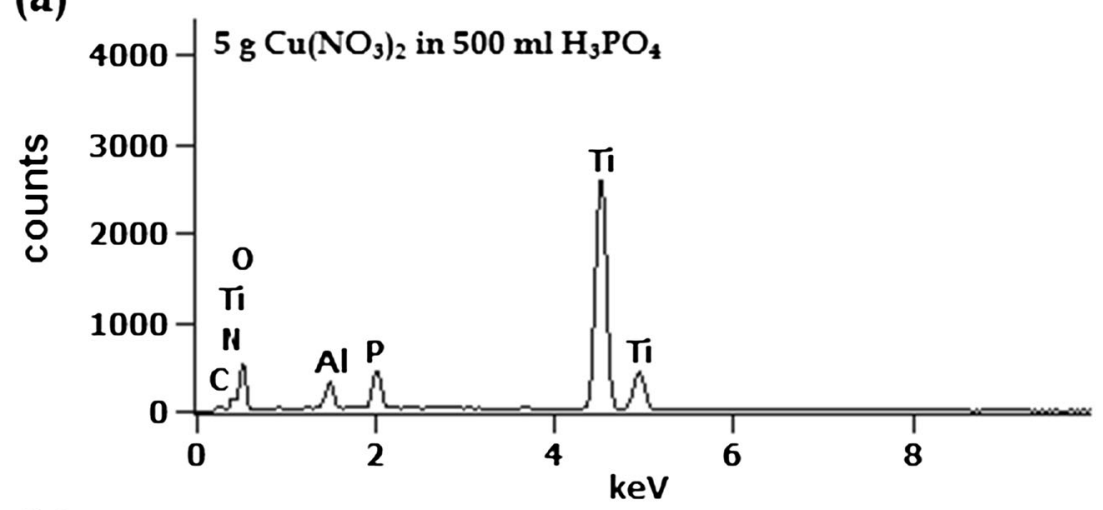

(b)

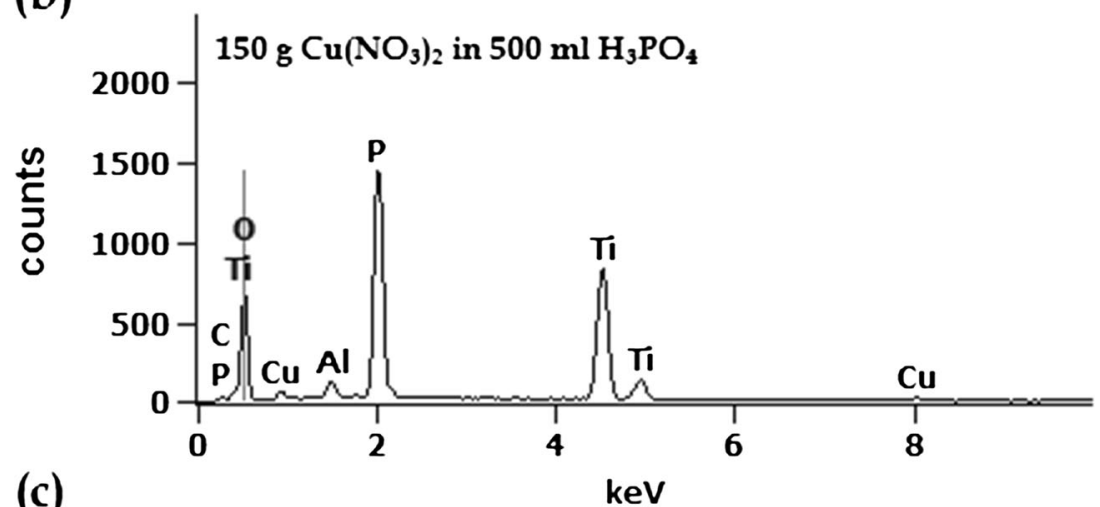

(c)

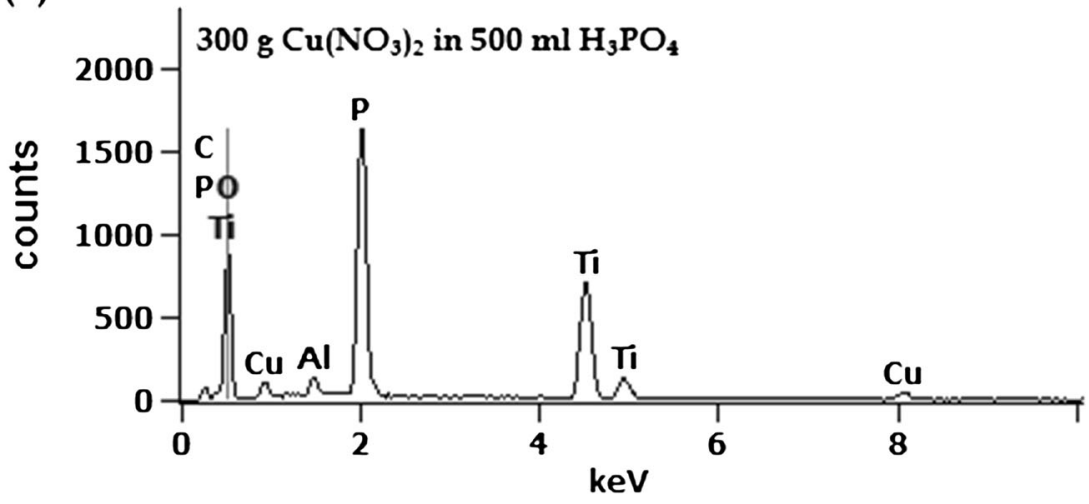


Table 1, the chemical composition of the obtained surface layer is presented. After treatment in that electrolyte, mainly titanium and aluminum were detected and finally one cannot verify, whether they come from the matrix or from the PEO surface layer. A very small amount of phosphorus (3.2 \pm $0.5 \mathrm{wt} \%)$ and a high oxygen amount $(43.5 \pm 0.4 \mathrm{wt} \%)$ in the surface layer were recorded. It may suggest that the surface layer formed after the PEO consists mainly of titanium oxides/ hydroxides with some small inclusions of titanium phosphates. With the EDS method, it was possible to detect neither carcinogenic vanadium nor bactericidal copper. In conclusion, it should be noted that the PEO treatment at the voltage of $450 \mathrm{~V}$ in electrolyte with a small amount of copper nitrate, i.e., about $0.05 \mathrm{~mol} / \mathrm{L}$, has not any practical meaning regarding the surface layer $\mathrm{Cu}$ element enrichment for biomedical application. In fact, there is lack of the porous surface layer and absence of the copper ions in the film obtained.

The PEO treatment in the electrolyte with much higher concentration of copper nitrate, i.e., about $1.60 \mathrm{~mol} / \mathrm{L}$, resulted in the appearance of the porosity that is depicted in Figs. 3 and 4. On the basis of Table 1, it is possible to conclude that the
Fig. 8 Box and whisker plots of the amount of phosphorus, aluminum, titanium, and copper in the surface layer formed on titanium Ti6A14V alloy after PEO at voltage of $450 \mathrm{~V}$ in electrolyte containing from 0.05 up to $3.20 \mathrm{~mol} / \mathrm{L}$ of $\mathrm{Cu}\left(\mathrm{NO}_{3}\right)_{2}$ in $\mathrm{H}_{3} \mathrm{PO}_{4}$
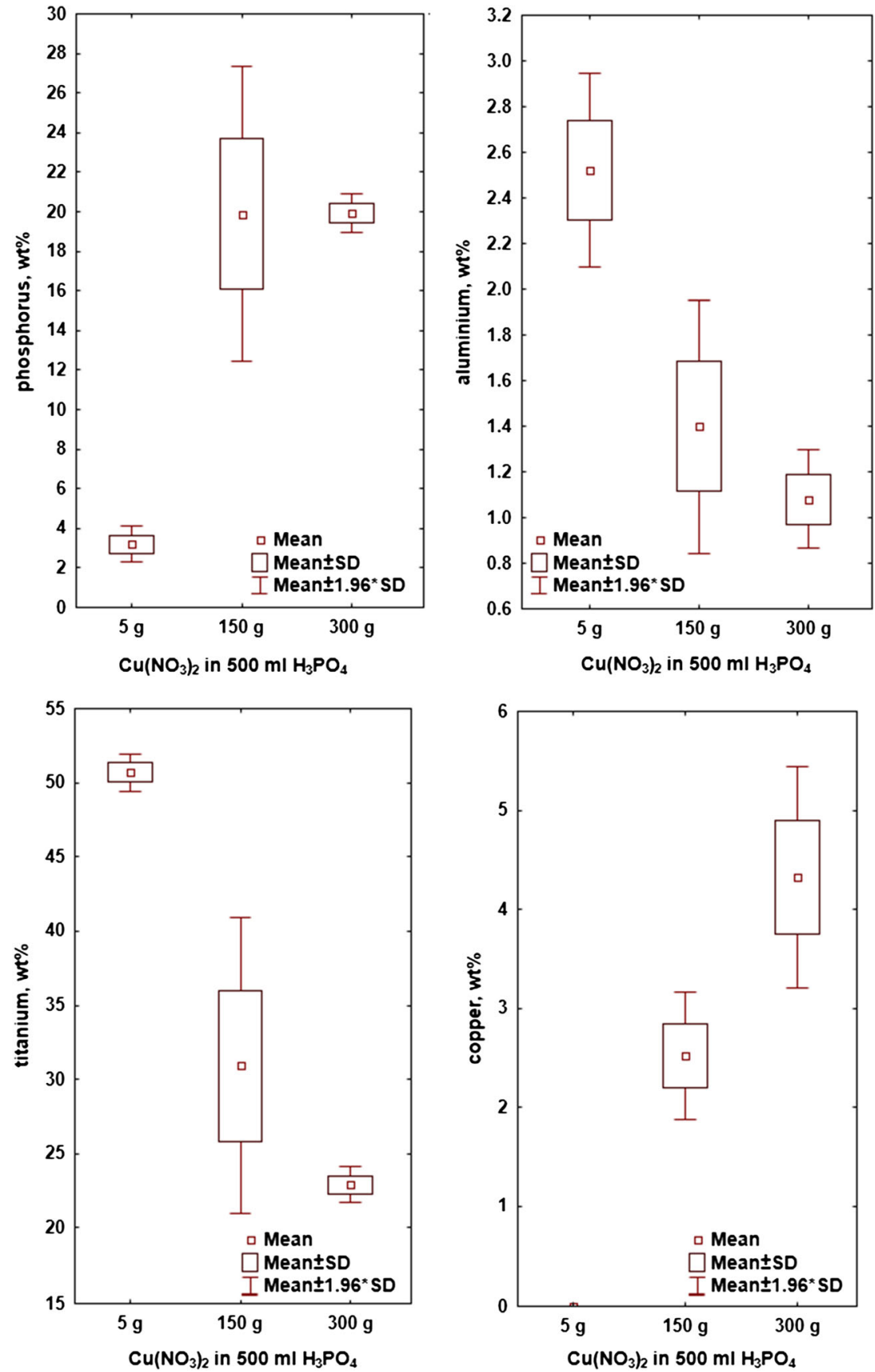
chemical composition is definitely different from the first one (concerning the sample after PEO treatment in $0.05 \mathrm{~mol} / \mathrm{L}$ of $\mathrm{Cu}\left(\mathrm{NO}_{3}\right)_{2}$ in $\mathrm{H}_{3} \mathrm{PO}_{4}$ electrolyte). In the surface layer, high amount of phosphorus $(19.9 \pm 3.8 \mathrm{wt} \%)$ and copper $(2.5 \pm$ $0.3 \mathrm{wt} \%$ ) were recorded. It may mean that the top surface layer consists of titanium and copper phosphates with some inclusions of oxides and hydroxides. Interestingly, the amount of aluminum is reduced to $1.4 \pm 0.3 \mathrm{wt} \%$. This may suggest that the aluminum signal originating from that element comes mainly from the matrix. Concerning the use of Ti6Al4V as a biomaterial, the information is very important because the aluminum may affect the acceleration of the Alzheimer's disease and Down syndrome subjects [30].

The standard thickness of the PEO coating is up to $10 \mu \mathrm{m}$, and it consists with at least of two sub-layers. The first one, inner and adjacent to the matrix, is relatively thin, corrosion resistant, and non-porous. It can be treated as a transition layer between matrix ( $\mathrm{Al} 6 \mathrm{wt} \%$, V $4 \mathrm{wt} \%$, Ti $90 \mathrm{wt} \%$ ) and the outer one, porous sub-layer, which consists mainly of titanium phosphates within copper ions and/or compounds with a very small amount of aluminum compounds. Most likely, it is formed at the beginning of the PEO process and during further processing time the porous outer layer is growing. The outer sub-layer of PEO coating has a small amount of aluminum inside, because the participation of that element decreases as it approaches to the outer surface. During that oxidation process, the outer surface layer is being created and simultaneously destroyed by micro arcs, resulting in, among others, formation of pores. However, the main material for the PEO coating creation is derived from electrolyte (phosphorus, copper, and oxygen) and from the titanium alloy treated (titanium). Assuming that the successive sub-layers are formed one on another one, and that each next forming sub-layer gets the building material from the previous sub-layer and electrolyte, one may easily explain why the outer sub-layer has so small amount of aluminum and lack of vanadium.

The plasma electrolytic oxidizing in the solution containing $3.20 \mathrm{~mol} / \mathrm{L}$ of $\mathrm{Cu}\left(\mathrm{NO}_{3}\right)_{2}$ in concentrated phosphoric acid resulted in the formation of a porous surface layer (Figs. 5 and 6 ) with the highest amount of copper $(4.3 \pm 0.6 \mathrm{wt} \%)$ and the smallest amount of aluminum $(1.1 \pm 0.1 \mathrm{wt} \%)$. The amount of phosphorus $(19.9 \pm 0.5 \mathrm{wt} \%)$ in the surface layer is similar to that recorded on the sample oxidized in the solution consisting of $1.60 \mathrm{~mol} / \mathrm{L}$ of $\mathrm{Cu}\left(\mathrm{NO}_{3}\right)_{2}$ in $\mathrm{H}_{3} \mathrm{PO}_{4}$. It should be noted that, if looking from the standpoint of biocompatibility, the obtained surface layer is the best one. The titanium phosphates enriched with the copper ions have revealed a porous structure which should be biocompatible and conducive to the osseointegration [31].

In Fig. 7, the EDS spectra of the surface layer formed on Ti6Al4V alloy after PEO at the voltage of $450 \mathrm{~V}$ in the electrolyte containing (a) 0.05 , (b) 1.60 , and (c) $3.20 \mathrm{~mol} / \mathrm{L}$ of $\mathrm{Cu}\left(\mathrm{NO}_{3}\right)_{2}$ in $\mathrm{H}_{3} \mathrm{PO}_{4}$ are displayed. As it was mentioned before, the surface layer compositions are given in Table 1. The highest signals from the PEO layers, formed in the electrolytes containing copper nitrate of 1.60 and $3.20 \mathrm{~mol} / \mathrm{L}$ of $85 \%$-concentrated phosphoric acid for phosphorus, were measured. The lowest signals from copper and aluminum were registered. In the case of the electrolyte of $1.60 \mathrm{~mol} / \mathrm{L}$ of copper nitrate, the aluminum amount was higher than that of copper, but most likely, the recorded aluminum signal has been derived from the matrix itself and the copper just from the PEO layer.

In Fig. 8, the box and whisker plots of the amount of phosphorus, aluminum, titanium, and copper in the surface layer formed on titanium Ti6Al4V alloy after PEO at the voltage of $450 \mathrm{~V}$ in electrolyte containing from 0.05 up to $3.20 \mathrm{~mol} / \mathrm{L}$ of $\mathrm{Cu}\left(\mathrm{NO}_{3}\right)_{2}$ in $85 \% \mathrm{H}_{3} \mathrm{PO}_{4}$ are presented.

Table 2 Significant $t$ test of the amount of phosphorus in the surface layer formed on Ti6Al4V alloy after PEO at voltage of $450 \mathrm{~V}$ in electrolyte containing from 5 to $300 \mathrm{Cu}\left(\mathrm{NO}_{3}\right)_{2}$ in $500 \mathrm{ml} \mathrm{H}_{3} \mathrm{PO}_{4}$ [41]

\begin{tabular}{|c|c|c|c|c|c|c|c|c|c|c|c|}
\hline \multirow{2}{*}{$\begin{array}{l}\text { Group } 1 \\
\text { vs group } 2\end{array}$} & \multicolumn{11}{|c|}{$t$ test for independent samples $\left(\right.$ Ti6al4V) ${ }^{\mathrm{a}}$} \\
\hline & $\begin{array}{l}\text { Mean } \\
\text { Group } 1\end{array}$ & $\begin{array}{l}\text { Mean } \\
\text { Group } 2\end{array}$ & $t$ value & df & $p$ value & $\begin{array}{l}\text { Valid } N \\
\text { Group } 1\end{array}$ & $\begin{array}{l}\text { Valid } N \\
\text { Group } 2\end{array}$ & $\begin{array}{l}\text { Standard deviation } \\
\text { Group } 1\end{array}$ & $\begin{array}{l}\text { Standard deviation } \\
\text { Group } 2\end{array}$ & $\begin{array}{l}F \text {-ratio } \\
\text { variances }\end{array}$ & $p$ variances \\
\hline 5 vs $5 \mathrm{~g}$ & 3.20000 & 3.20000 & 0.0000 & 8 & 0.000000 & 5 & 5 & 0.458258 & 0.458258 & 1.00000 & 1.000000 \\
\hline 5 vs $150 \mathrm{~g}$ & 3.20000 & 19.88000 & -9.7472 & 8 & 0.000010 & 5 & 5 & 0.458258 & 3.798947 & 68.72381 & 0.001222 \\
\hline 5 vs $300 \mathrm{~g}$ & 3.20000 & 19.92000 & -54.7095 & 8 & 0.000000 & 5 & 5 & 0.458258 & 0.506952 & 1.22381 & 0.849546 \\
\hline 150 vs $5 \mathrm{~g}$ & 19.88000 & 3.20000 & 9.7472 & 8 & 0.000010 & 5 & 5 & 3.798947 & 0.458258 & 68.72381 & 0.001222 \\
\hline 150 vs $150 \mathrm{~g}$ & 19.88000 & 19.88000 & 0.0000 & 8 & 1.000000 & 5 & 5 & 3.798947 & 3.798947 & 1.00000 & 1.000000 \\
\hline 150 vs $300 \mathrm{~g}$ & 19.88000 & 19.92000 & -0.0233 & 8 & 0.981953 & 5 & 5 & 3.798947 & 0.506952 & 56.15564 & 0.001815 \\
\hline 300 vs $5 \mathrm{~g}$ & 19.92000 & 3.20000 & 54.7095 & 8 & 0.000000 & 5 & 5 & 0.506952 & 0.458258 & 1.22381 & 0.849546 \\
\hline 300 vs $150 \mathrm{~g}$ & 19.92000 & 19.88000 & 0.0233 & 8 & 0.981953 & 5 & 5 & 0.506952 & 3.798947 & 56.15564 & 0.001815 \\
\hline 300 vs $300 \mathrm{~g}$ & 19.92000 & 19.92000 & 0.0000 & 8 & 1.000000 & 5 & 5 & 0.506952 & 0.506952 & 1.000000 & 1.000000 \\
\hline
\end{tabular}

Data in italics means significant difference in the data comparison

${ }^{\text {a }}$ Variables were treated as independent samples 
Table 3 Significant $t$ test of the amount of aluminum in the surface layer formed on Ti6Al4V alloy after PEO at voltage of $450 \mathrm{~V}$ in electrolyte containing from 5 to $300 \mathrm{~g} \mathrm{Cu}\left(\mathrm{NO}_{3}\right)_{2}$ in $500 \mathrm{ml} \mathrm{H}_{3} \mathrm{PO}_{4}$ [41]

Group $1 \quad t$ test for independent samples (Ti6al4V) ${ }^{\mathrm{a}}$

vs group 2

Mean Mean $t$ value df $p$ value $\quad$ Valid $N$ Valid $N$ Standard deviation Standard deviation $F$-ratio $p$ variances

Group 1 Group 2 Group 1 Group 2 Group $1 \quad$ Group 2 variances

\begin{tabular}{lllllllllllll}
\hline $5 \mathrm{vs} 5 \mathrm{~g}$ & 2.520000 & 2.520000 & 0.0000 & 8 & 1.000000 & 5 & 5 & 0.216795 & 0.216795 & 1.000000 & 1.000000 \\
$5 \mathrm{vs} 150 \mathrm{~g}$ & 2.520000 & 1.400000 & 7.0275 & 8 & 0.000110 & 5 & 5 & 0.21795 & 0.282843 & 1.702128 & 0.619008 \\
$5 \mathrm{vs} 300 \mathrm{~g}$ & 5.520000 & 1.080000 & 13.2563 & 8 & 0.000001 & 5 & 5 & 0.216795 & 0.109545 & 3.916667 & 0.214550 \\
$150 \mathrm{vs} 5 \mathrm{~g}$ & 1.400000 & 2.520000 & -7.0275 & 8 & 0.0001100 & 5 & 5 & 0.282843 & 0.216795 & 1.702128 & 0.619008 \\
$150 \mathrm{vs} 150 \mathrm{~g}$ & 1.400000 & 1.400000 & 0.0000 & 8 & 1.000000 & 5 & 5 & 0.282843 & 0.282843 & 1.000000 & 1.000000 \\
$150 \mathrm{vs} 300 \mathrm{~g}$ & 1.400000 & 1.080000 & 2.3591 & 8 & 0.046025 & 5 & 5 & 0.282843 & 0.109545 & 6.666667 & 0.093203 \\
$300 \mathrm{vs} 5 \mathrm{~g}$ & 1.080000 & 2.520000 & -13.2563 & 8 & 0.000001 & 5 & 5 & 0.109545 & 0.216795 & 3.916667 & 0.214550 \\
$300 \mathrm{vs} 150 \mathrm{~g}$ & 1.080000 & 1.400000 & -2.3591 & 8 & 0.046025 & 5 & 5 & 0.109545 & 0.282843 & 6.666667 & 0.093203 \\
$300 \mathrm{vs} 300 \mathrm{~g}$ & 1.08000 & 1.080000 & 0.0000 & 8 & 1.000000 & 5 & 5 & 0.109545 & 0.109545 & 1.000000 & 1.000000 \\
\hline
\end{tabular}

Data in italics means significant difference in the data comparison

${ }^{\text {a }}$ Variables were treated as independent samples

For the statistics [38-41] presented in Table 1 and Fig. 8, three samples were selected for measurements five times repeated each. Additionally, in Tables 2, 3, 4, and 5, the significant $t$ tests of the amount of phosphorus, titanium, and copper in the surface layer formed on Ti6Al4V alloy after PEO at the voltage of $450 \mathrm{~V}$ in the electrolyte containing from 0.05 up to $3.20 \mathrm{~mol} / \mathrm{L}$ of $\mathrm{Cu}\left(\mathrm{NO}_{3}\right)_{2}$ in $85 \% \mathrm{H}_{3} \mathrm{PO}_{4}$ are displayed.

On the basis of Tables 2, 3, 4, and 5 and Fig. 8, it is visible that there are significant differences in the amounts of aluminum, titanium, and copper in between the surface layers formed during PEO in each of the electrolytes studied. The amount of phosphorus in the PEO layer is the same after oxidizing in the solution containing $1.60 \mathrm{~mol} / \mathrm{L}$ as well as $3.20 \mathrm{~mol} / \mathrm{L}$ of copper nitrate in $85 \%$-concentrated $\mathrm{H}_{3} \mathrm{PO}_{4}$ acid. However, the standard deviation $(0.5 \mathrm{wt} \%)$ and the range (1.1 wt\%) obtained from the statistical analysis (Table 1) for the phosphorus after the processing in the electrolyte containing the highest amount of copper nitrate $(3.20 \mathrm{~mol} / \mathrm{L})$ were lower than those obtained after oxidizing in the electrolyte consisting of $1.60 \mathrm{~mol} / \mathrm{L}$ of $\mathrm{Cu}\left(\mathrm{NO}_{3}\right)_{2}$ in $\mathrm{H}_{3} \mathrm{PO}_{4}$, i.e., the standard deviation and the range were equal to 14.43 and $9.2 \mathrm{wt} \%$, respectively.

The authors propose the following mathematic formulae describing the weight percent of main elements of the surface layer except for the oxygen, which can be also in carbon compounds' contaminations. The formulae can help to predict the chemical compositions of the surface layers formed after the PEO in the electrolyte consisting of concentrated phosphoric acid and copper nitrate. The function argument $x$ is the amount of

Table 4 Significant $t$ test of the amount of titanium in the surface layer formed on Ti6Al4V alloy after PEO at voltage of $450 \mathrm{~V}$ in electrolyte containing from 5 to $300 \mathrm{~g} \mathrm{Cu}\left(\mathrm{NO}_{3}\right)_{2}$ in $500 \mathrm{ml} \mathrm{H}_{3} \mathrm{PO}_{4}$ [41]

\begin{tabular}{|c|c|c|c|c|c|c|c|c|c|c|c|}
\hline \multirow{2}{*}{$\begin{array}{l}\text { Group } 1 \text { vs } \\
\text { group } 2\end{array}$} & \multicolumn{11}{|c|}{$t$ test for independent samples $(\text { Ti6al } 4 \mathrm{~V})^{\mathrm{a}}$} \\
\hline & $\begin{array}{l}\text { Mean } \\
\text { Group } 1\end{array}$ & $\begin{array}{l}\text { Mean } \\
\text { Group } 2\end{array}$ & $t$ value & $\mathrm{df}$ & $p$ value & $\begin{array}{l}\text { Valid } N \\
\text { Group } 1\end{array}$ & $\begin{array}{l}\text { Valid } N \\
\text { Group } 2\end{array}$ & $\begin{array}{l}\text { Standard deviation } \\
\text { Group } 1\end{array}$ & $\begin{array}{l}\text { Standard deviation } \\
\text { Group } 2\end{array}$ & $\begin{array}{l}F \text {-ratio } \\
\text { variances }\end{array}$ & $p$ variances \\
\hline 5 vs $5 \mathrm{~g}$ & 50.70000 & 50.70000 & 0.0000 & 8 & 1.000000 & 5 & 5 & 0.644205 & 0.644205 & 1.00000 & 1.00000 \\
\hline 5 vs $150 \mathrm{~g}$ & 50.70000 & 30.94000 & 8.6383 & 8 & 0.000025 & 5 & 5 & 0.644205 & 5.074249 & 62.04337 & 0.001494 \\
\hline 5 vs $300 \mathrm{~g}$ & 50.70000 & 22.90000 & 69.5000 & 8 & 0.000000 & 5 & 5 & 0.644205 & 0.620484 & 1.07792 & 0.943776 \\
\hline 150 vs $5 \mathrm{~g}$ & 30.94000 & 50.70000 & -8.6383 & 8 & 0.000025 & 5 & 5 & 5.074249 & 0.644205 & 62.04337 & 0.001494 \\
\hline 150 vs $150 \mathrm{~g}$ & 30.94000 & 30.94000 & 0.0000 & 8 & 1.000000 & 5 & 5 & 5.074249 & 5.074249 & 1.00000 & 1.000000 \\
\hline 150 vs $300 \mathrm{~g}$ & 30.94000 & 22.90000 & 3.5168 & 8 & 3.5168 & 5 & 5 & 5.074249 & 0.620484 & 66.87792 & 0.001289 \\
\hline 300 vs $5 \mathrm{~g}$ & 22.90000 & 50.70000 & -69.5000 & 8 & 0.000000 & 5 & 5 & 0.620484 & 0.644205 & 1.07792 & 0.943776 \\
\hline 300 vs $150 \mathrm{~g}$ & 22.90000 & 30.94000 & -3.5168 & 8 & 0.007883 & 5 & 5 & 0.620484 & 5.074249 & 66.87792 & 0.001289 \\
\hline 300 vs $300 \mathrm{~g}$ & 22.90000 & 22.90000 & 0.0000 & 8 & 1.000000 & 5 & 5 & 0.620484 & 0.620484 & 1.00000 & 1.000000 \\
\hline
\end{tabular}

Data in italics means significant difference in the data comparison

${ }^{\text {a }}$ Variables were treated as independent samples 
Table 5 Significant $t$ test of the amount of copper in the surface layer formed on Ti6Al4V alloy after PEO at voltage of $450 \mathrm{~V}$ in electrolyte containing from 5 to $300 \mathrm{~g} \mathrm{Cu}\left(\mathrm{NO}_{3}\right)_{2}$ in $500 \mathrm{ml} \mathrm{H}_{3} \mathrm{PO}_{4}$ [41]

\begin{tabular}{|c|c|c|c|c|c|c|c|c|c|c|c|}
\hline \multirow{2}{*}{$\begin{array}{l}\text { Group } 1 \text { vs group } \\
2\end{array}$} & \multicolumn{11}{|c|}{$t$ test for independent samples $(\text { Ti6al } 4 \mathrm{~V})^{\mathrm{a}}$} \\
\hline & $\begin{array}{l}\text { Mean } \\
\text { Group } 1\end{array}$ & $\begin{array}{l}\text { Mean } \\
\text { Group } 2\end{array}$ & $t$ value & $\mathrm{df}$ & $p$ value & $\begin{array}{l}\text { Valid } \\
N \\
\text { Group } \\
1\end{array}$ & $\begin{array}{l}\text { Valid } \\
N \\
\text { Group } \\
2\end{array}$ & $\begin{array}{l}\text { Standard } \\
\text { deviation } \\
\text { Group } 1\end{array}$ & $\begin{array}{l}\text { Standard } \\
\text { deviation } \\
\text { Group } 2\end{array}$ & $\begin{array}{l}F \text {-ratio } \\
\text { variances }\end{array}$ & $\begin{array}{l}p \\
\text { variances }\end{array}$ \\
\hline 5 vs $300 \mathrm{~g}$ & 0.000000 & 4.320000 & -16.8925 & 8 & 0.000000 & 5 & 5 & 0.000000 & 0.571839 & 0.000000 & 1.000000 \\
\hline 5 vs $150 \mathrm{~g}$ & 0.000000 & 2.520000 & -17.2264 & 8 & 0.000000 & 5 & 5 & 0.000000 & 0.327109 & 0.000000 & 1.000000 \\
\hline 5 vs $5 \mathrm{~g}$ & 0.000000 & 0.000000 & & 8 & & & 5 & 0.000000 & 0.000000 & & \\
\hline 150 vs $300 \mathrm{~g}$ & 2.520000 & 4.320000 & -6.1096 & 8 & 0.000286 & 5 & 5 & 0.327109 & 0.571839 & 3.056075 & 0.304760 \\
\hline 150 vs $150 \mathrm{~g}$ & 2.520000 & 2.520000 & 0.0000 & 8 & 1.000000 & 5 & 5 & 0.327109 & 0.327109 & 1.000000 & 1.000000 \\
\hline 150 vs $5 \mathrm{~g}$ & 2.520000 & 0.000000 & 17.2264 & 8 & 0.000000 & 5 & 5 & 0.327109 & 0.000000 & 0.000000 & 1.000000 \\
\hline 300 vs $300 \mathrm{~g}$ & 4.320000 & 4.320000 & 0.0000 & 8 & 1.000000 & 5 & 5 & 0.571839 & 0.571839 & 1.000000 & 1.000000 \\
\hline 300 vs $150 \mathrm{~g}$ & 4.320000 & 2.520000 & 6.1096 & 8 & 0.000286 & 5 & 5 & 0.571839 & 0.327109 & 3.056075 & 0.304760 \\
\hline 300 vs 5 g & 4.320000 & 0.000000 & 16.8925 & 8 & 0.000000 & 5 & 5 & 0.571839 & 0.000000 & 0.000000 & 1.000000 \\
\hline
\end{tabular}

Data in italics means significant difference in the data comparison

${ }^{\text {a }}$ Variables were treated as independent samples

copper nitrate, from 0.05 to $3.20 \mathrm{~mol} / \mathrm{L}$, in the $85 \%$ concentrated $\mathrm{H}_{3} \mathrm{PO}_{4}$ acid:

$\left\{\begin{array}{c}\mathrm{Cu}=0.014 \cdot x+0.061, \quad R^{2}=0.95 \\ \mathrm{P}=4.158 \cdot \ln x-3.414, \quad R^{2}=0.99 \\ \mathrm{Ti}=-0.094 \cdot x+49.1, R^{2}=0.89 \\ \mathrm{Al}=-0.004 \cdot x+2.404, R^{2}=0.82\end{array}\right.$

The main goal of mathematical equations presented above is to describe the PEO coating formed on titanium alloy. The use of that description provides a possibility to perform a basic optimization, i.e., finding out the PEO treatment conditions for which the POE coating contains the lowest amount of aluminum and the highest amount of copper in the structure. Given mathematical relations can be used just in relation to the experiment conditions, i.e., to arguments (copper nitrate amount) from 0.05 to $3.20 \mathrm{~mol} / \mathrm{L}$, in the $85 \%$-concentrated $\mathrm{H}_{3} \mathrm{PO}_{4}$ acid. The formulae were obtained on the basis of three- level statistical plan within five repetitions of each measurement. The coefficients of determination, which describe how well data are fitted to a statistical model, are not less than $95 \%$, what should be considered as a very good PEO coating model consisting of the four mathematical equations.

Additionally, on the basis of the obtained EDS results, the $\mathrm{Cu} / \mathrm{P}$ and $\mathrm{Cu} / \mathrm{Ti}$ ratios were found, with the mathematical equations

$$
\begin{aligned}
& \mathrm{Cu} \\
& \mathrm{Ti} \\
& \text { and }
\end{aligned}
$$

$\frac{\mathrm{Cu}}{\mathrm{P}}=77 \cdot 10^{-5} \cdot x\left(R^{2}=0.92\right)$

describing the function of the copper nitrate content $(x)$ in electrolyte.

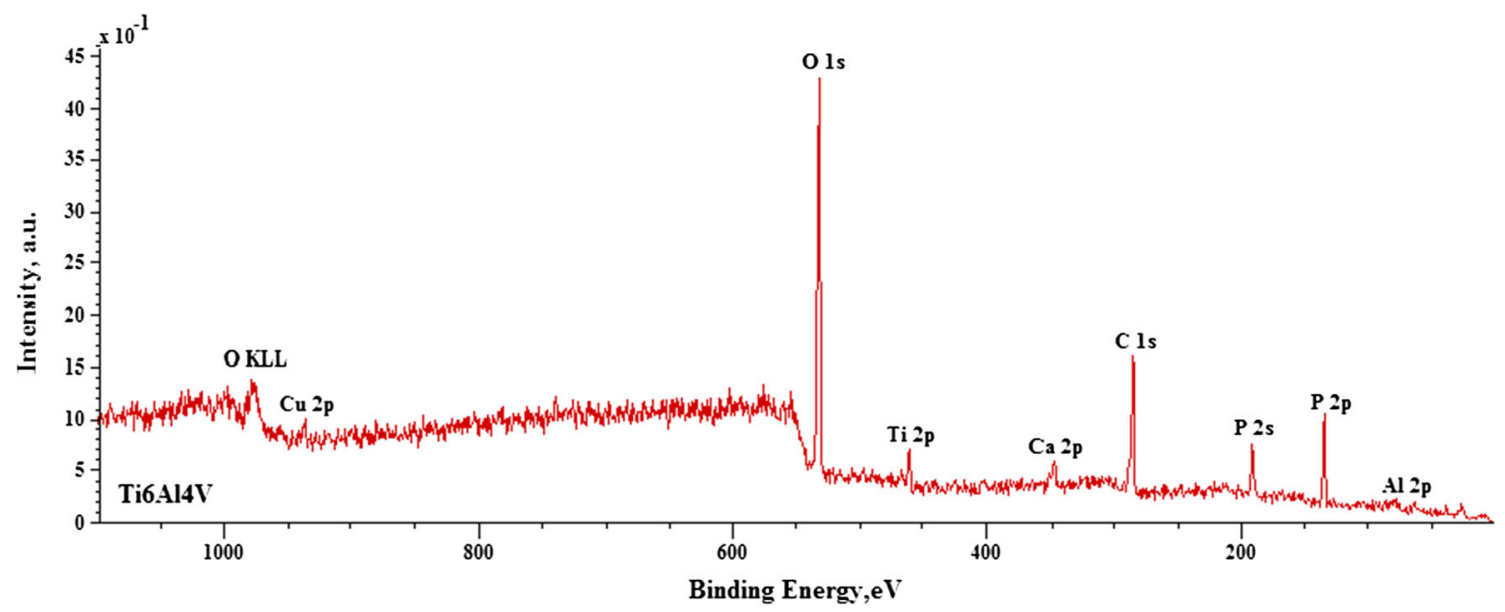

Fig. 9 Survey XPS spectra of the surface layer formed on Ti6Al4V alloy after PEO 
Table 6 Carbon contamination in nano-layer formed on Ti6Al4V, at $\%$

\section{TI6AL4V, CARBON CONTAMINATION NANO-LAYER, at\%}

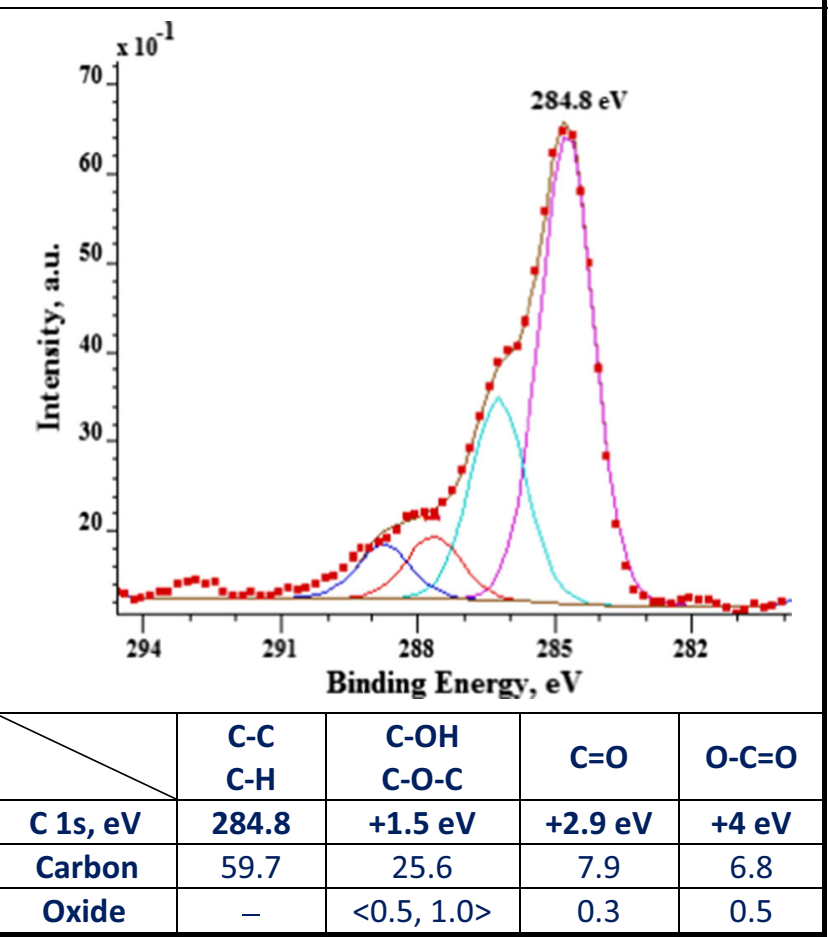

XPS analysis allows to get information about the chemical composition on a depth of about $10 \mathrm{~nm}$, which should be considered as a contact layer with human tissue. These results should help to determine exactly the conditions for using the plasma electrolytic oxidation treatment to reduce the risk of appearance of $\mathrm{Al}$ and $\mathrm{V}$ compounds and receive the required amount of copper in the surface coating.

The XPS spectra of the surface layer formed on Ti6Al4V alloy after PEO in the electrolyte consisting of 3.20 and $1.60 \mathrm{~mol} / \mathrm{L}$ of copper nitrate in $85 \%$-concentrated $\mathrm{H}_{3} \mathrm{PO}_{4}$ acid are shown in Fig. 9. The high signals of titanium (Ti 2p), aluminum (Al 2p), copper ( $\mathrm{Cu} 2 \mathrm{p})$, and phosphorus ( $\mathrm{P} 2 \mathrm{p})$ as well as oxygen (O 1s) and carbon ( $\mathrm{C} 1 \mathrm{~s})$ can be noted. The oxygen bonded with carbon (a contamination layer), presented in Table 6, was separated from that one bonded with chemical elements of surface layers, that is presented in Table 7. The carbon-oxygen ratio in the contamination layer was solved based on the stoichiometric rules. The carbon contamination layer formed on Ti6Al4V alloy after PEO consists of carbon and oxygen at about 72 and 28 at $\%$, respectively.
The high-resolution XPS spectra of titanium (Ti 2p), aluminum (Al 2p), vanadium (V 2p), copper ( $\mathrm{Cu} 2 \mathrm{p})$, phosphorus (P 2p), and oxygen (O 1s) are presented in Fig. 10. The binding energies of $\mathrm{Ti} 2 \mathrm{p}_{3 / 2}$ and $\mathrm{Ti} 2 \mathrm{p}_{1 / 2}$ equaling to 460.4 and $466.6 \mathrm{eV}$, respectively, can suggest the presence of titanium on the fourth stage of oxidation $\left(\mathrm{Ti}^{4+}\right)$ in the surface layer to occur $[38,39]$. On the basis of $\mathrm{O} 1 \mathrm{~s}$ and $\mathrm{P} 2 \mathrm{p}$ spectra analysis, where the maxima amount for 532.1 and $134.3 \mathrm{eV}$, respectively, it can be concluded that most likely in the top layer, the titanium phosphates $\mathrm{Ti}_{3}\left(\mathrm{PO}_{4}\right)_{4}$ are present.

Concerning copper content, the resolution $\mathrm{Cu} 2 \mathrm{p}$ XPS spectra of the surface layer formed on Ti6Al4V alloy after PEO are displayed in Fig. 11. The smallest peak, i.e., at $932.1 \mathrm{eV}(\mathrm{FWHM}=0.5)$ and $933.5(\mathrm{FWHM}=1.6)$ can be interpreted as $\mathrm{Cu}^{+}$(copper I oxide) and $\mathrm{Cu}^{2+}$ (copper II oxide and/or hydroxide), respectively. All the main highest peaks, i.e., these with the binding energies of $935.5 \mathrm{eV}$ (FWHM= $1.8)$ and $937.2(\mathrm{FWHM}=1.8)$ may be interpreted as $\mathrm{Cu}^{2+}$ $\left(\mathrm{Cu}_{3}\left(\mathrm{PO}_{4}\right)_{2}\right.$ [26-28] and/or $\mathrm{Cu}_{2} \mathrm{PO}_{4} \mathrm{OH}$ [40]. The other peaks at the higher binding energies may be treated as $\mathrm{Cu}^{\text {sat }}$ satellite peaks [39].

The $\mathrm{Cu} 2 \mathrm{p}$ binding energies equaling to 935.9, 937.3, 943.3, and $945.3 \mathrm{eV}$ suggest that copper in the surface layer is on the second level of oxidation $\left(\mathrm{Cu}^{2+}\right)$ and most likely can be interpreted as $\mathrm{Cu}_{3}\left(\mathrm{PO}_{4}\right)_{2}$ and/or $(\mathrm{Ti}, \mathrm{Cu})_{x}\left(\mathrm{PO}_{4}\right)_{y}$. The maximum in spectrum $\mathrm{Al} 2 \mathrm{p}$ overlapped with $\mathrm{Cu} 3 \mathrm{p}$, and it is most likely assigned to $\mathrm{Cu}^{2+}[26,27]$. The rest of the binding energies suggest that the aluminum is on the third stage of oxidation $\left(\mathrm{Al}^{3+}\right)$. Summing up, it should be noted that the surface layer consists mainly of $\mathrm{Ti}^{4+}, \mathrm{Al}^{3+}, \mathrm{Cu}^{2+}$, and $\mathrm{PO}_{4}{ }^{3-}$, which may form the compounds such as $(\mathrm{Ti}, \mathrm{Al}, \mathrm{Cu})_{3}\left(\mathrm{PO}_{4}\right)_{y}$. In Table 7, there are presented quantitative results of the chemical composition of the surface layer (top of $10 \mathrm{~nm}$ of PEO layer).

It is visible that mainly phosphates $\mathrm{PO}_{4}{ }^{3-}$ (17.2 at $\%$ phosphorus and $68.7 \mathrm{at} \%$ oxygen) were detected. In the obtained surface layer, the aluminum (6.8 at $\%)$ and phosphorus anaerobic (Ti,Al,Cu)-P compounds (3.8 at $\%$ ) as well as titanium (2.5 at $\%$ ), were detected. In addition, the $\mathrm{Cu} / \mathrm{P}, \mathrm{Al} / \mathrm{P}, \mathrm{Cu} / \mathrm{Ti}$, $\mathrm{P} / \mathrm{Ti}$, and $\mathrm{Al} / \mathrm{Ti}$ ratios from XPS results for Ti6Al4V are presented below:

$\frac{C u}{P}=4.8 ; \quad \frac{A l}{P}=0.3 ; \quad \frac{C u}{T i}=40 ; \quad \frac{P}{T i}=8.4 ; \quad \frac{A l}{T i}=2.7$

Biomaterial scaffolds [42, 43] as well as the whole alloys such as magnesium and/or magnesium-zinc alloys [44-48]

Table 7 PEO nano-layer formed on Ti6Al4V (at $\%)$

$$
10 \text { nm PEO layer on Ti6A14V (at\%) }
$$

\begin{tabular}{|c|c|c|c|c|c|c|}
\hline Titanium & Aluminum & Vanadium & Copper & Oxygen in $\mathrm{PO}_{4}{ }^{3-}$ & $\mathrm{PO}_{4}{ }^{3-}$ & (Ti, Al, Cu)-P \\
\hline 2.5 & 6.8 & 0 & 1.0 & 68.7 & 17.2 & 3.8 \\
\hline
\end{tabular}



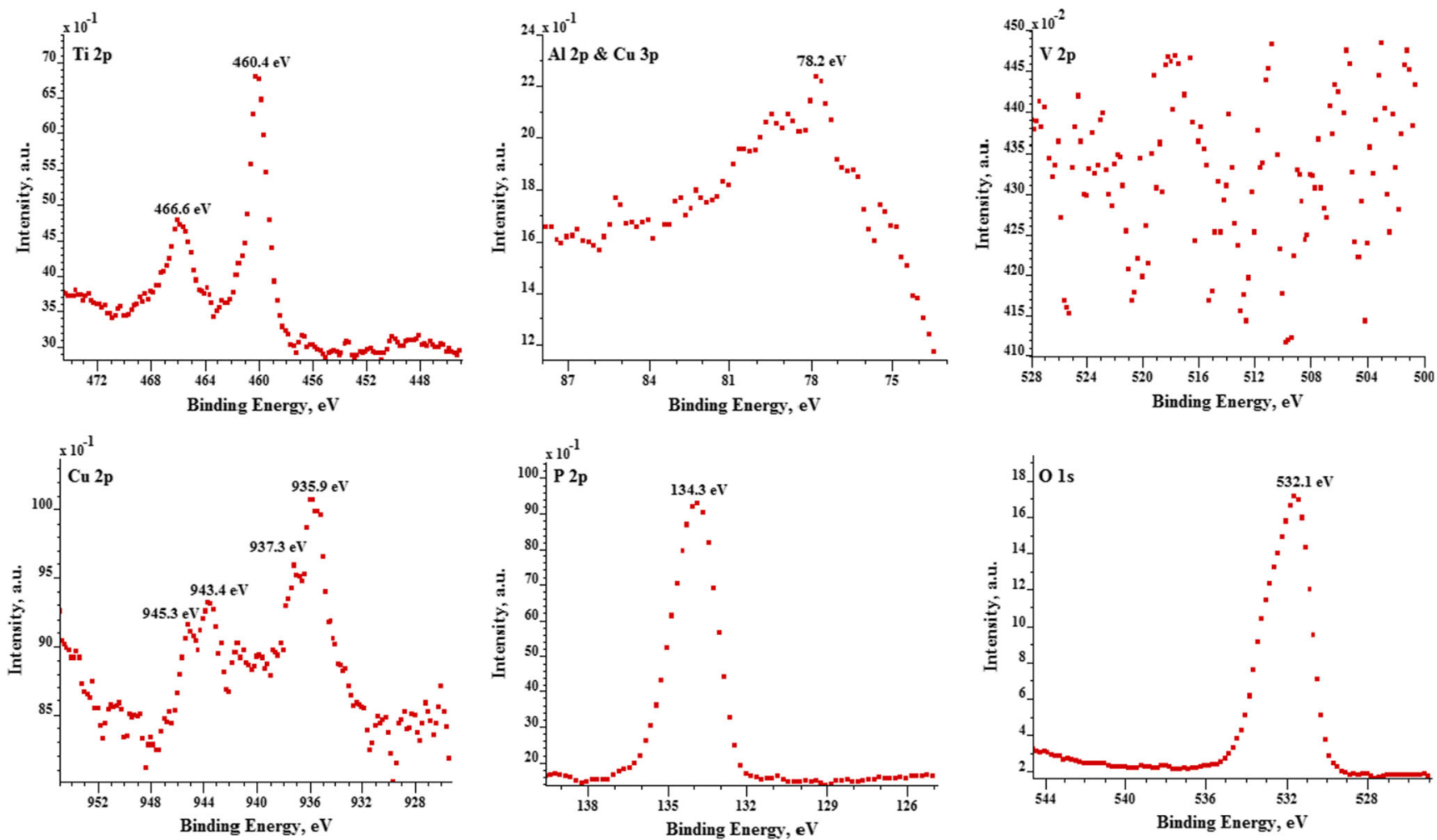

Fig. 10 High-resolution XPS spectra of the surface layer formed on Ti6A14V alloy after PEO

can be fully degraded in a human body. In case of presented in this paper the study results, the outer part of the PEO coating has to be biodegradable to enable cells to produce their own extracellular matrix. However, the inner sub-layer of the PEO coating created should be compact and corrosion resistant. Therefore, the main idea was to prepare the porous surface on Ti6Al4V alloy sample which will be formed mainly of phosphates within copper ions and/or compounds inside.

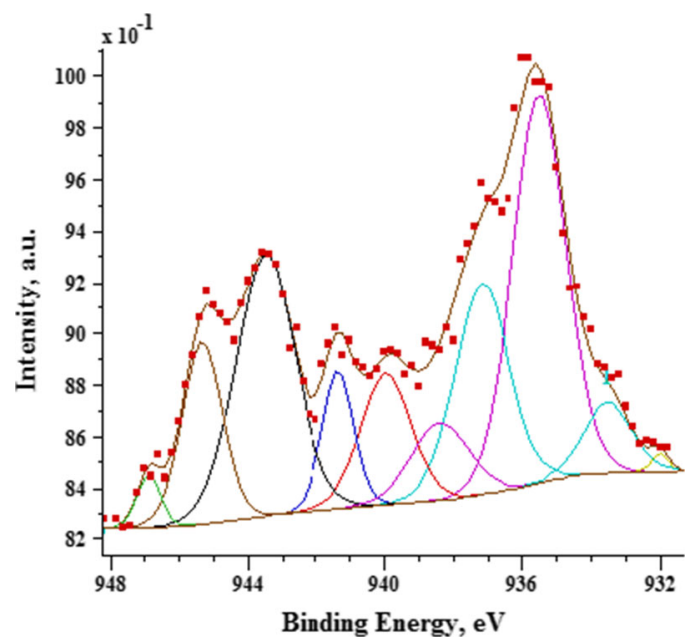

\begin{tabular}{|c|c|c|c|c|c|c|c|c|c|c|}
\hline BE [eV] & 932.0 & 933.5 & 935.5 & 937.2 & 938.4 & 940.0 & 941.3 & 943.5 & 945.3 & 946.9 \\
\hline FWHM & 0.5 & 1.6 & 1.8 & 1.8 & 1.9 & 1.7 & 1.1 & 2.0 & 1.4 & 0.8 \\
\hline $\mathbf{a t} \%$ & 0.4 & 4.5 & 27.6 & 5.2 & 5.9 & 8.7 & 5.8 & 20.7 & 9.7 & 1.7 \\
\hline
\end{tabular}

Fig. 11 High-resolution $\mathrm{Cu} 2 \mathrm{p}$ XPS spectra of the surface layer formed on Ti6Al4V alloy after PEO
The biological research is planned to be developed and implemented in the next stage of the study to conclude that the obtained biomaterial samples used for scaffolds will be biocompatible and biodegradable. Thus, on the basis of available literature, one can suppose that the main conditions referred to the abovementioned biocompatibility and biodegradability should be complied.

The work generally covers a technological approach to biomaterial surface processing. Our plan for the future is to start with biological tests, provisioned for a different team of specialists, as soon as the technological part of the study is completed. The purpose of the study is to know the PEO processing so that all the mechanisms are understood. The aim is to achieve the biomaterial surface state in which the patient re-operation to change the implant is not necessary. Titanium alloys have very good durability and corrosion resistance in human electrolytes/body fluids. With a proper surface preparation of the biomaterial implant having contact with human tissue, such as the proposed PEO treatment, it will be possible to exclude a need for re-operation.

\section{Conclusions}

The following conclusions may be formulated after the PEO treatment of Ti6Al4V alloy, first concerning the SEM/EDS results: 
1. The electrochemical non-traditional machining-treatment of PEO method is proposed.

2. Copper ions can be introduced into the surface layer of Ti6Al4V alloy by the novel plasma electrolytic oxidation (PEO) in the electrolyte consisting of copper nitrate and concentrated phosphoric acid.

3. Statistical analysis applied for the experimental data treatment indicates the optimum conditions for the PEO process can be determined.

4. The copper to other elements ratios were determined to choose the optimum values on demand.

Besides, the XPS study allowed to reveal that the surface layer after PEO consists mainly of titanium and aluminum phosphates with copper ions inserted in the volume of the coating. In addition to the phosphates, it was found that also, anaerobic phosphorus compounds with titanium and/or aluminum and copper ions are present in the coating. The valuable feature of the proposed PEO treatment is eliminating vanadium and a considerable diminishing of aluminum from the surface coating.

Acknowledgments Dra G. Vara and Dra M.B. García-Blanco from Fundación Cidetec, Parque Tecnológico de San Sebastián $\mathrm{P}^{\circ}$ Miramón, 19620009 Donostia-San Sebastián (Gipuzkoa), Spain, are highly acknowledged for delivering Ti6Al4V material for the PEO experiments.

Prof. Dr.-Ing. Winfried Malorny and Dr Torsten Barfels from Hochschule Wismar, Germany, are given thanks for providing access to the SEM/EDS apparatus allowing to perform the studies.

Open Access This article is distributed under the terms of the Creative Commons Attribution 4.0 International License (http:// creativecommons.org/licenses/by/4.0/), which permits unrestricted use, distribution, and reproduction in any medium, provided you give appropriate credit to the original author(s) and the source, provide a link to the Creative Commons license, and indicate if changes were made.

\section{References}

1. Yerokhin AL, Nie X, Leyland A, Matthews A, Dowey SJ (1999) Plasma electrolysis for surface engineering. Surf Coat Technol 122(2-3):73-93

2. Yerokhin AL, Nie X, Leyland A, Matthews A, Dowey SJ (2000) Characterisation of oxide films produced by plasma electrolytic oxidation of a Ti-6Al-4V alloy. Surf Coat Technol 130(2-3):195-206

3. Wheeler JM, Collier CA, Paillard JM, Curran JA (2010) Evaluation of micromechanical behaviour of plasma electrolytic oxidation (PEO) coatings on Ti-6Al-4V. Surf Coat Technol 204(21-22):339-3409

4. Krzakala A, Mlynski J, Dercz G, Michalska J, Maciej A, Nieuzyla L, Simka W (2014) Modification of Ti-6Al-4V alloy surface by EPDPEO process in $\mathrm{ZrSiO}_{4}$ suspension. Arch Metall Mater 59(1):199-204

5. Hryniewicz T, Rokosz K (2010) Analysis of XPS results of AISI $316 \mathrm{~L}$ SS electropolished and magnetoelectropolished at varying conditions. Surf Coatings Technol 204(16-17):2583-2592

6. Hryniewicz T, Rokosz K (2010) Polarization characteristics of magnetoelectropolishing stainless steels. Mater Chem Phys 122(1):169-174
7. Rokosz K, Hryniewicz T, Raaen S (2012) Characterization of passive film formed on AISI $316 \mathrm{~L}$ stainless steel after magnetoelectropolishing in a broad range of polarization parameters. Steel Res Int 83(9):910-918

8. Hryniewicz T, Rokosz K (2010) Investigation of selected surface properties of AISI 316L SS after magnetoelectropolishing. Mater Chem Physic 123(1):47-55

9. Hryniewicz T, Rokosz K (2014) Corrosion resistance of magnetoelectropolished AISI 316L SS biomaterial. Anti-Corros Methods Mater 61(2):57-64

10. Rokosz K, Hryniewicz T, Simon F, Rzadkiewicz S (2015) Comparative XPS analysis of passive layers composition formed on AISI 304 L SS after standard and high-current density electropolishing. Surf Interface Anal 47(1):87-92

11. Rokosz K, Lahtinen J, Hryniewicz T, Rzadkiewicz S (2015) XPS depth profiling analysis of passive surface layers formed on austenitic AISI 304L and AISI 316L SS after high-current-density electropolishing Surf Coat Technol 276:516-520. doi:10.1016/j. surfcoat.2015.06.022

12. Hryniewicz T, Rokosz K, Rokicki R, Prima F (2015) Nanoindentation and XPS studies of titanium TNZ alloy after electrochemical polishing in a magnetic field. Materials 8(1):205-215

13. Hryniewicz T, Rokosz K, Valiček J, Rokicki R (2012) Effect of magnetoelectropolishing on nanohardness and Young's modulus of titanium biomaterial. Mater Lett 83:69-72

14. Rokosz K, Hryniewicz T (2010) Pitting corrosion resistance of AISI 316L stainless steel in Ringer's solution after magnetoelectrochemical polishing. Corrosion 66(3):035004

15. Hryniewicz T, Konarski P, Rokosz K, Rokicki R (2011) SIMS analysis of hydrogen content in near surface layers of AISI $316 \mathrm{~L}$ SS after electrolytic polishing under different conditions. Surface Coatings Technol 205(17-18):4228-4236

16. Hryniewicz T, Rokosz K, Zschommler SHR (2012) SEM/EDX and XPS studies of niobium after electropolishing. Appl Surf Sci 263:357361

17. Rokosz K, Hryniewicz T, Raaen S (2014) Cr/Fe ratio by XPS spectra of magnetoelectropolished AISI 316L SS fitted by Gaussian-Lorentzian shape lines. Tehnicki Vjesnik-Technical Gazette 21(3):533-538

18. Rokosz K, Hryniewicz T, Raaen S (2015) SEM/EDX, XPS, corrosion and surface roughness characterization of AISI 316L SS after electrochemical treatment in concentrated $\mathrm{HNO}_{3}$. Tehnicki Vjesnik-Technical Gazette 22(1):125-131

19. Rokicki R, Hryniewicz T, Pulletikurthi C, Rokosz K, Munroe N (2015) Towards a better corrosion resistance and biocompatibility improvement of Nitinol medical devices. J Mater Eng Perform 24: 1634-1640. doi:10.1007/s11665-015-1429-x (7 pages)

20. Jelinek M, Kocourek T, Remsa J, Weiserová M, Jurek K, Mikšovský J, Strnad J, Galandáková A, Ulrichováe J (2013) Antibacterial, cytotoxicity and physical properties of laser-silver doped hydroxyapatite layers. Mater Sci Eng C 33(3):1242-1246

21. Mishra G, Dash B, Pandey S, Mohanty PP (2013) Antibacterial actions of silver nanoparticles incorporated $\mathrm{Zn}-\mathrm{Al}$ layered double hydroxide and its spinel. J Environ Chem Eng 1(4):1124-1130

22. Rajendran A, Pattanayak DK (2014) Silver incorporated antibacterial, cell compatible and bioactive titania layer on Ti metal for biomedical applications. RSC Advances 106(4):61444-61455

23. Trujillo NA, Oldinski RA, Ma H, Bryers JD, Williams JD, Popat KC (2012) Antibacterial effects of silver-doped hydroxyapatite thin films sputter deposited on titanium. Mater Sci Eng C 32(8):2135-2144

24. Hempel F, Finke B, Zietz C, Bader R, Weltmann K-D, Polak M (2014) Antimicrobial surface modification of titanium substrates by means of plasma immersion ion implantation and deposition of copper. Surf Coatings Technol 256:52-58

25. Kobayashi E, Wang T, Doi H (1988) Mechanical properties and corrosion resistance of Ti-6Al-7Nb alloy dental castings. J Mater Sci Mater Med 9:567-574 
26. J. Łaskawiec, R. Michalik, Theoretical and application issues in implants, Publishing House of Silesian University of Technology, Gliwice, 2002 (in Polish)

27. Simka W (2013) Habilitation summary of professional accomplishments (in Polish). Silesian University of Technology (Wydział Chemiczny Politechniki Śląskiej), Gliwice, Chemical Engineering Department, pp 1-18

28. Ku CH, Pioletti DP, Browne M, Gregson PJ (2002) Effect of different Ti-6Al-4V surface treatments on osteoblasts behaviour. Biomaterials 23:1447-1454

29. Bellows CG, Heersche JN, Aubin JE (1999) Aluminium accelerates osteoblastic differentiation but is cytotoxic in long-term rat calvaria cell cultures. Calcif Tissue Int 65:59-65

30. Krewski D, Yokel RA, Nieboer E, Borchelt D, Cohen J, Harry J, Kacew S, Lindsay J, Mahfouz AM, Rondeau V (2007) Human health risk assessment for aluminium, aluminium oxide, and aluminium hydroxide. J Toxicol Environ Health B Crit Rev 10(1):1269

31. Solving Titanium Implant Osseointegration Problems by Using Epoxy/Carbon-Fiber-Reinforced Composite, Titanium Today, 2015, 26-28.

32. Browne RC (1995) Vanadium poisoning from gas turbines. Br J Ind Med 2(12):57-59

33. Jacobs JJ, Skipor AK, Black J, Urban R, Galante JO (1991) Release and excretion of metal in patients who have a total hip-replacement component made of titanium-base alloy. The J Bone Joint Surg 73: $1475-1486$

34. Aluminum CAS \# 7429-90-5, PUBLIC HEALTH STATEMENT, Agency for Toxic Substances and Disease Registry, Division of Toxicology and Environmental Medicine, http://www.atsdr.cdc. gov Atlanta, 2008.

35. Davidson JA, Mishra AK, Kovasc P, Poggie RA (1994) New surface-hardened, low-modulus, corrosion-resistant Ti-13Nb-13Zr alloy for total HIP arthroplasty. Bio-Med Mater Eng 4:231-243

36. Landsberg JP, McDonald B, Watt F (1992) Absence of aluminium in neuritic plaque cores in Alzheimer's disease. Nature 360:65-68

37. Seiler HG, Sigel H, Sigel A (1998) Handbook of toxicity of inorganics compounds. Marcel Dekker Inc., New York, NY

38. Biesinger MC, Lau LWM, Gerson AR, Smart RSC (2010) Resolving surface chemical states in XPS analysis of first row transition metals, oxides and hydroxides: $\mathrm{Sc}, \mathrm{Ti}, \mathrm{V}, \mathrm{Cu}$ and $\mathrm{Zn}$. Appl Surf Sci 257:887-898

39. C.D. Wagner, A.V. Naumkin, A. Kraut-Vass, J.W. Allison, C.J. Powell, J.R.Jr. Rumble, NIST Standard Reference Database 20, 2003, Version 3.4. web version: srdata.nist.gov/xps

40. Cho I-S, Kim DW, Lee S, Kwak CH, Bae S-T, Noh JH, Yoon SH, Jung HS, Kim D-W, Hong KS (2008) Synthesis of $\mathrm{Cu}_{2} \mathrm{PO}_{4} \mathrm{OH}$ hierarchical superstructures with photocatalytic activity in visible light. Adv Funct Mater 18:2154-2162

41. StatSoft, Inc. (2011). STATISTICA (data analysis software system), version 10. www.statsoft.com

42. Zhang H, Zhou L, Zhang W (2014) Control of scaffold degradation in tissue engineering: a review. Tissue Eng Part B Rev 20(5):492502. doi:10.1089/ten.TEB.2013.0452

43. Stevens MM (2008) Biomaterials for bone tissue engineering. Mater today 11(5):18-25

44. Jinghuai Zhang, Chi Xu, Yongbin Jing, Shuhui Lv, Shujuan Liu, Daqing Fang, Jinpeng Zhuang, Milin Zhang, Ruizhi Wu, New horizon for high performance Mg-based biomaterial with uniform degradation behavior: formation of stacking faults, Scientific Reports 5, 2015, Article number: 13933; DOI:10.1038/srep13933

45. Pil-Ryung Cha, Hyung-Seop Han, Gui-Fu Yang, Yu-Chan Kim, KiHa Hong, Seung-Cheol Lee, Jae-Young Jung, Jae-Pyeong Ahn, Young-Yul Kim, Sung-Youn Cho, Ji Young Byun, Kang-Sik Lee, Seok-Jo Yang, Hyun-Kwang Seok, Biodegradability engineering of biodegradable $\mathrm{Mg}$ alloys: Tailoring the electrochemical properties and microstructure of constituent phases, Scientific Reports 3, 2013, Article number: 2367; DOI:10.1038/srep02367

46. Persaud-Sharma D, McGoron A (2012) Biodegradable magnesium alloys: a review of material development and applications. J Biomim Biomater Tissue Eng 12:25-39. doi:10.4028/www. scientific.net/JBBTE. 12.25

47. Kirkland Nicholas T (2012) Magnesium biomaterials - past, present and future. Corros Eng Sci Technol 47(5):322-328

48. H.F. Li, X.H. Xie, Y.F. Zheng, Y. Cong, F.Y. Zhou, K.J. Qiu, X. Wang, S.H. Chen, L. Huang, L. Tian, L. Qin, Development of biodegradable $\mathrm{Zn}-1 \mathrm{X}$ binary alloys with nutrient alloying elements $\mathrm{Mg}, \mathrm{Ca}$ and Sr, Scientific Reports 5, 2015, Article number: 10719; DOI:10.1038/srep10719 